\title{
A case of Goldenhar syndrome with rare associations of post axial polydactyly and situs inversus
}

\begin{abstract}
Goldenhar-Gorlin syndrome or Oculo-auriculo-vertebral dysplasia is a congenital condition with abnormalities of head and bones of spinal column. It results from abnormal morphogenesis of first and second branchial arches, resulting in disruption of normal facial development. We report a case of Goldenhar Syndrome admitted in our unit but with a rare association of postaxial polydactyly. Though Goldenhar syndrome is not rare, the unusual presence of postaxial polydactyly prompted us to report this case.
\end{abstract}

Keywords: goldenhar syndrome, hemi-facial microsomia, oculo-auriculo-vertebral spectrum, polydactyly, situs inversus
Volume 8 Issue 2 - 2018

\section{Sowjanya SVNS, Rahaman MA}

Department of Pediatrics, Govt Siddhartha Medical college and hospital, India

\section{Correspondence: Dr Sowjanya SVNS, DNB Neonatology Trainee, Department of Neonatology, Mehta multispecialty} hospitals Ind Pvt Ltd, India, Email: drsowjanya.svns@gmail.com

Received: December 14, 2017| Published: April 16, 2018

\section{Introduction}

Goldenhar-Gorlin syndrome or First and Second Branchial Arch syndrome or Oculo-auriculo-vertebral dysplasia is a congenital condition with abnormalities of head and bones of spinal column. It results from abnormal morphogenesis of first and second branchial arches, resulting in disruption of normal facial development. ${ }^{1}$ When the movement and development of these tissues is disrupted, the face may have abnormal openings, underdevelopment and excess skin. It was first described by Dr. Maurice Goldenhar in $1952 .{ }^{2}$ Incidence is one in 3000-5000 live births with male predominance. ${ }^{3}$ Sporadic in most of the cases. However, $1-2 \%$ of cases occur in families with autosomal dominant transmission. Prognosis is good.

\section{Case presentation}

We report a case of full term, appropriate for gestational age, male baby born at 38 weeks out of non-consanguineous marriage to 27 year old primi mother with a married life of 15 years. Mother is seropositive for retro-viral disease which was diagnosed antenatally. The baby was admitted due to dysmorphic appearance on day 1 of life. There were no h/o congenital malformations in any of the family members. No h/o exposure to radiation or drugs during pregnancy. No history suggestive of use of medications for fertility. Baby was conscious and alert. His vital parameters were within normal limits.

\section{General examination}

1. Facial asymmetry involving left temporal, maxillary and mandibular regions (Figure 1).

2. Low set ears with microtia left side, meatal stenosis and five preauricular skin tags (Figure 2).

3. Ocular hypotelorism (canthal index $<0.32$ ) with a canthal index of 0.27 and left micropthalmia (Figure 3).

4. Macrostomia and high arched palate.

5. Short neck (neck length: length ratio $=1: 15$ normal being 1:13), webbing of neck and low posterior hair line (Figure 4).
6. Unilateral left upper limb post axial polydactyly (Figure 5).

7. Right undescended testis.

8. Anthropometry: Microcephaly ( $\mathrm{HC}<3^{\text {rd }}$ centile for boys at birth) and short trunk (US: LS ratio=1.5:1).

\section{Systemic Examination}

Respiratory system, Abdomen, Neurological examination was normal.

Cardiovascular system: Heart sounds better heard on the right side.

Fundus: Normal.

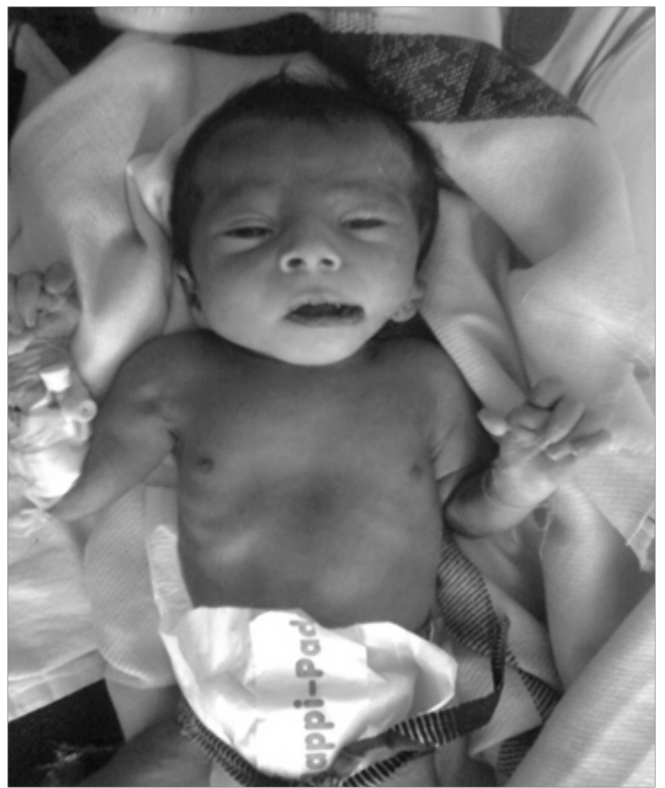

Figure I Facial asymmetery with macrostomia. 


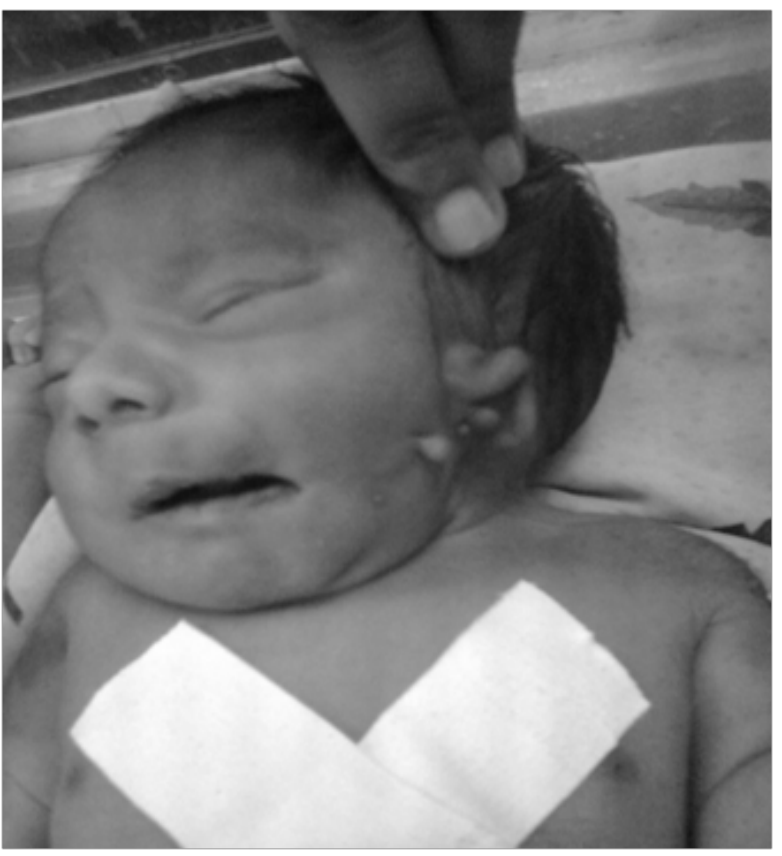

Figure 2 Preauricular skin tags.

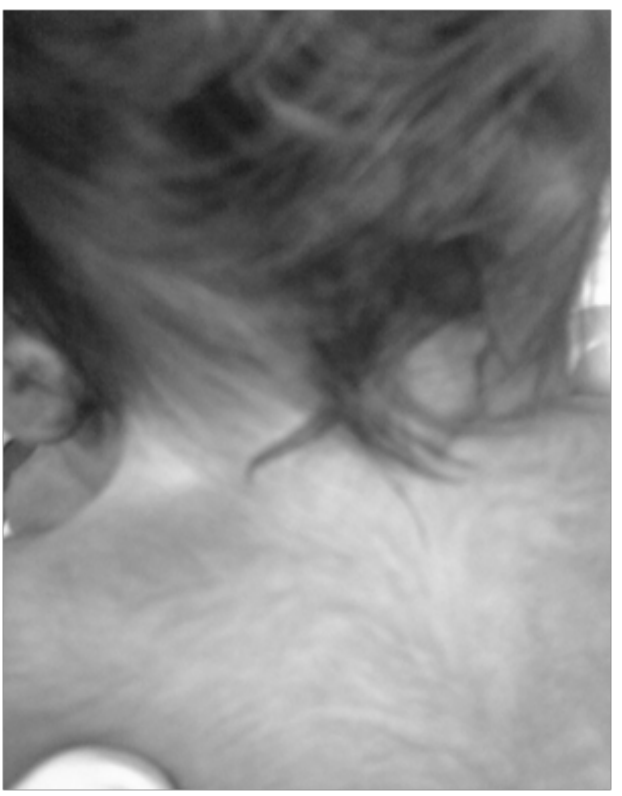

Figure 4 Webbing of the neck.

\section{Investigations}

1. X-ray erect abdomen including chest showed situs in versus totalis (Figure 6).

2. X-ray cervical spine AP and Lateral views showed cervical hemivertibrae (Figure 7).

3. Ultrasound abdomen showed normal study.

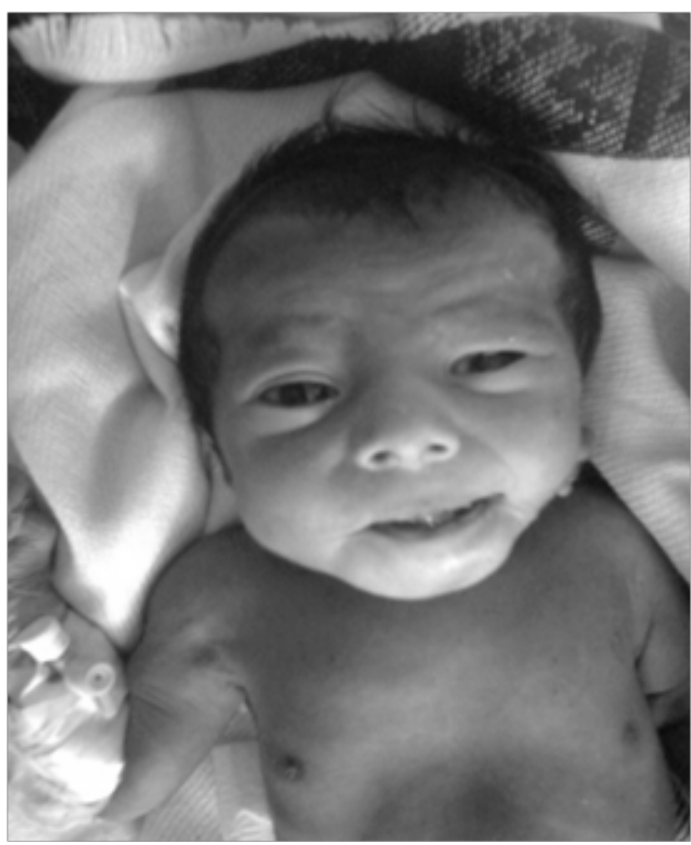

Figure 3 Occular hypotelorism and left microphthalmia.

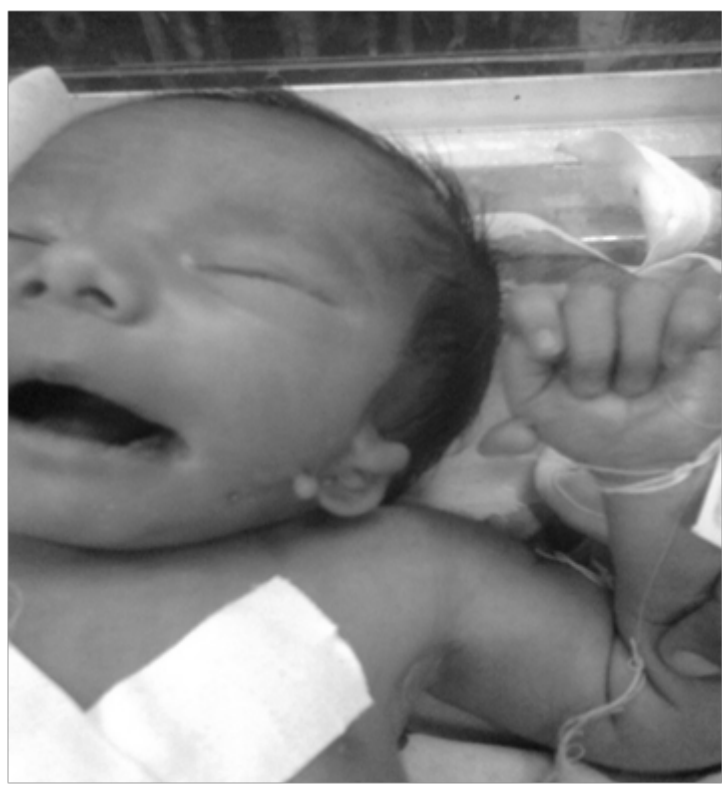

Figure 5 Left upperlimb postaxial polydactyly.

4. CT scan brain plain showed normal study.

5. 2D Echocardiogram showed

(a) Situs in versus with dextrocardia.

(b) Large ASD with L-R shunt.

(c) Tiny apical muscular VSD with L-R shunt.

(d) Dilated coronary sinus. 
(e) Right aortic arch.

(f) Normal valves and biventricular function.

The baby was diagnosed as a case of Goldenhar syndrome based on the clinical features and investigations. Baby was started on nevirapine prophylaxis. Formula feeds were started with paladai after consent

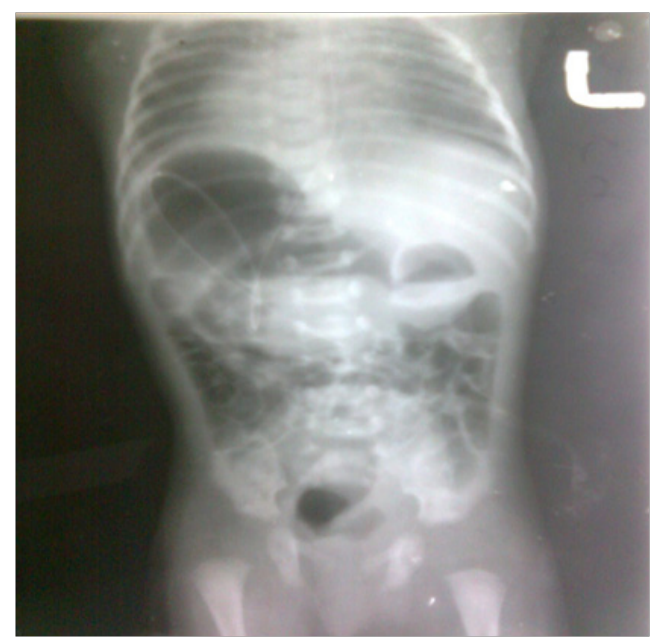

Figure 6 Xray chest with abdomen showing situs inversus totalis.

\section{Discussion}

Oculo-auriculo-vertebral (OAV) spectrum is often used synonymously with Goldenhar syndrome and hemi-facial microsomia (HFM). But it refers to 3 rare disorders representing the range of severity of the same disorder

(a) OAV disorder-mildest form.

(b) Hemi facial microsomia- intermediate form.

(c) Goldenhar syndrome-most severe form.

Goldenhar syndrome is a multi-organ involvement with varied clinical features.

\section{Major components}

1. Hemi facial microsomia. ${ }^{5}$

2. Ocular anomalies-Inferio-temporal epibulbar dermoids $(75 \%){ }^{6-8}$ Lipodermoids $(50 \%)^{6-8} \quad$ Upper eyelid coloboma, Micropthalmia, Hypotelorism, Blepharophimosis, Strabismus ${ }^{9}$

3. Vertebral anomalies ${ }^{10}-$ Scoliosis $(50 \%)$, Cervical hemi vertebrae (30\%) Spina bifida.

\section{Minor components}

1. Auricular ${ }^{11}:$ Anotia or microtia

Meatal stenosis, Pre-auricular skin tags, Conductive hearing loss, Low set ears from the parents. Mother was taught feeding and handling of the baby. Baby was discharged home on day 5 of life. Baby was readmitted on day 15 of life with lethargy, poor feeding and abdominal distension. Clinical examination and laboratory investigations were suggestive of late onset sepsis. Baby was ventilated and died on day 18 of life.

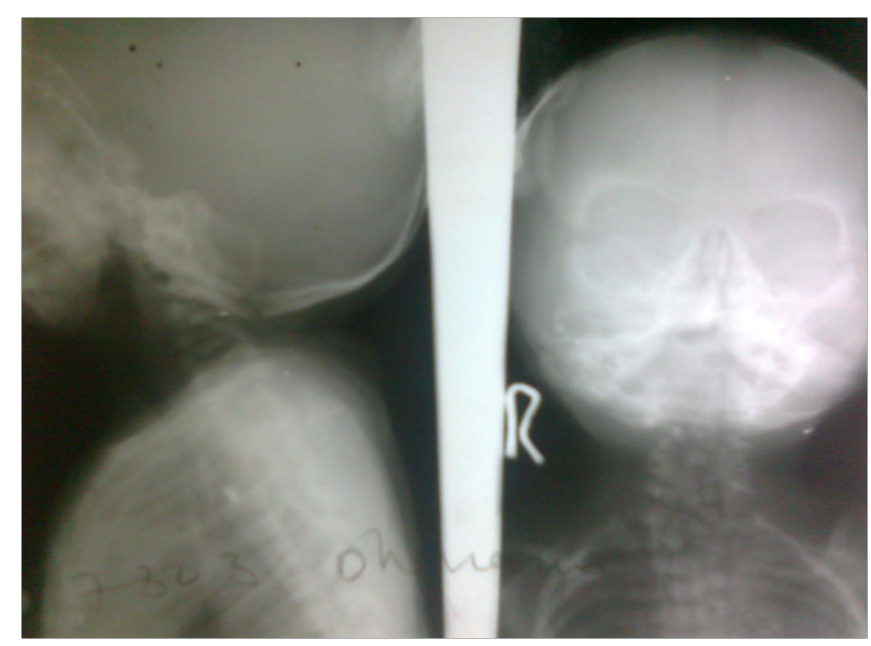

Figure 7 Cervival hemivertebrae.

2. Cranio-facial defects: Cleft lip and palate $(10 \%),{ }^{12}$ Macrostomia $^{13}$

3. Congenital heart defects- $-5-58 \%$ cases $^{14}$

$32 \%-V S D$, TOF and ASD

$39 \%$-Conotruncal defects

$14 \%$-Targeted growth defects

07\%-Situs and looping defects

04\%-PDA and Left sided obstructive lesion

4. Gastrointestinal system ${ }^{16}$-Tracheo-esophageal fistula, Umbilical and inguinal hernias

5. Genito-urinary anomalies ${ }^{17}-$ Renal ectopia, Hydronephrosis, Undescended testes Chordae

6. Others-Abnormal ribs, CTEV, Short neck, Webbing of neck, Low posterior hair line, Sprengel's deformity

Our case shows most of the manifestations of Goldenhar syndrome with a rare association of unilateral left upper limb post axial polydactyly and situs inversus totalis which prompted to report this case. Another interesting point is the presence of HIV infection in the mother. It is not known whether HIV infection can cause congenital malformations like this. The care of the baby from diagnosis to follow up has been summarized in Figure 8 Flow diagram (CARE Guidelines). We have done literature search and found out the previous cases reported in Table 1. Polydactyly has been reported previously as rare association but situs inversus is never reported till date in goldenhar syndrome. 
Table I Summary of previous case reports

\begin{tabular}{|c|c|c|c|c|c|}
\hline $\begin{array}{l}\text { Author, year } \\
\text { and country }\end{array}$ & Age & Sex & Consanguinity & Clinical features & Associations \\
\hline $\begin{array}{l}\text { Khadilkar et al } \\
2001 \text {, India }\end{array}$ & 6 mon & Female & Yes & $\begin{array}{l}\text { Absent left pinna, pre auricular tags, epibulbar } \\
\text { dermoid, macrostomia, left mandibular } \\
\text { hypoplasia }\end{array}$ & Congenital hypothyroidism \\
\hline $\begin{array}{l}\text { Amitava das et } \\
\text { al }{ }^{19} 2008 \text { India }\end{array}$ & 7 mon & Male & No & $\begin{array}{l}\text { Epibulbar dermoid, microtia, hemi facial } \\
\text { microsomia and cleft lip }\end{array}$ & Hypoplastic thumb \\
\hline $\begin{array}{l}\text { Kumar et } \mathrm{al}^{20} \\
2000 \text { India }\end{array}$ & $\begin{array}{l}\text { II } \\
\text { days }\end{array}$ & Female & No & $\begin{array}{l}\text { Left epibulbar dermoid, microtia, preauricular } \\
\text { tags, bifid tongue }\end{array}$ & $\begin{array}{l}\text { Polydactyly left foot and } \\
\text { obstructed hydrocephalus }\end{array}$ \\
\hline $\begin{array}{l}\text { Saxena et } \mathrm{al}^{21} \\
2012 \text { India }\end{array}$ & 25 yrs & Male & Yes & $\begin{array}{l}\text { Mid face retrusion, mandibular hypoplasia, left } \\
\text { corneal plaque, fissured tongue }\end{array}$ & None \\
\hline $\begin{array}{l}\text { Sharma et } \mathrm{al}^{22} \\
2006 \text { India }\end{array}$ & 12 yrs & Male & Not known & $\begin{array}{l}\text { Right torticollis, left microtia, right LMN facial } \\
\text { palsy, right conductive hearing loss, short neck, } \\
\text { block vertebrae }\end{array}$ & Right hand polydactyly \\
\hline $\begin{array}{l}\text { Taksande et al } \\
2013 \text {, India }\end{array}$ & 8 yrs & Male & No & Bilateral microtia and ear tags, short neck, & Left pre axial polydactyly \\
\hline $\begin{array}{l}\text { Barbosa et al }{ }^{23} \\
2003 \text { Brazil }\end{array}$ & II yrs & Female & No & $\begin{array}{l}\text { Facial asymmetry, hypoplasia of the mandible, } \\
\text { dermoid epibulbar tumor on the left eye } \\
\text { and birthmarks on the upper lip and palate }\end{array}$ & None \\
\hline
\end{tabular}

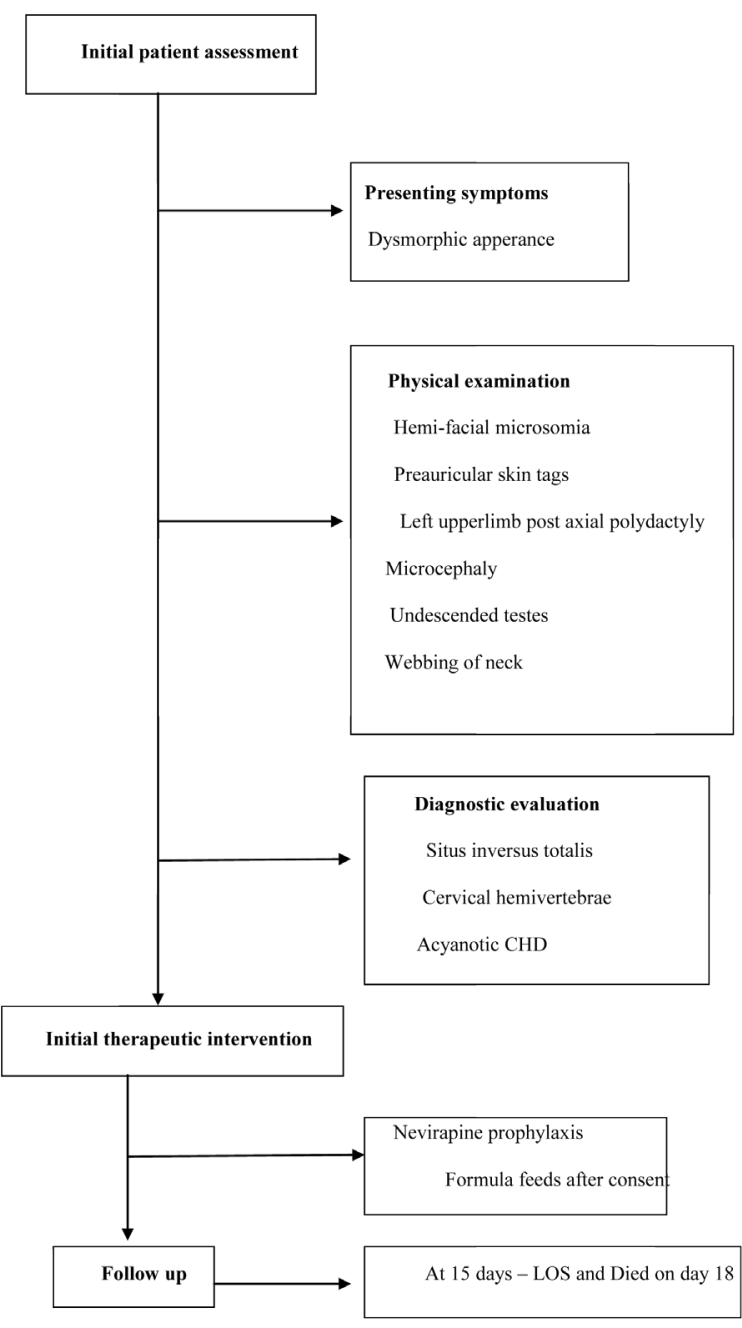

Figure 8 Care flow diagram.

\section{Acknowledgements}

None.

\section{Conflicts of interests}

Authors declare that there is no conflict of interest.

\section{References}

1. Ryan CA, Finer NN, Ives E, et al. Discordance of signs in monozygotic twins concordant for the Goldenhar anomaly. Am J Med Genet. 1988;29:755-61.

2. Goldenhar M. Associations malformatives de l'oeil et l'oreille, en particulier le syndrome dermoide épibulbaire-appendices auriculairesfistula auris congenita et ses relations avec la dysostose mandibulofaciale. J Genet Hum. 1952;1:243-82.

3. Grabb WC. The first and second brachial arch syndromes. Plast Reconstr Surg. 1965;36(5):485-508.

4. Pinheiro AL, Araújo LC, Oliveira SB, et al. Goldenhar's syndrome: Case report. Braz Dent J. 2003;14(1):67-70.

5. Taksande A, Vilhekar KY, Jain M. Atypical presentation of Goldenhar syndrome. J MGIMS. 2006;11:45-52.

6. Jones KL. Oculo-auriculo-vertebral spectrum In Smith's Recognizable Patterns of Human Malformation Philadelphia' W B Saunders Co. 1996; p 642-45.

7. Sherman RP, Roofman J, Ha Point JS. Dermoids clinical presentation a management. Br J Ophthal. 68(9):642-52.

8. Ziauras E, Farbew MCC. Diamond CCA pedunculated lipodermoid in auriculovertebral dysplasia. Arch Ophthal.1990;108:2032-33.

9. Zaka-ur-Rab Z, Mittal S. Optic Nerve Head Drusen in Goldenhar Syndrome. JK Science. 2007;9(1):33-34.

10. Gibson JN, Sillence DO, Taylor TK. Abnormalities of the spine in Goldenhar's syndrome. J Pediatr Orthop. 1996;16(3):344-349.

11. S Jaison SG, Batra N. Goldenhar Syndrome with multiple additional 
anomalies. Indian J Opthalmol. 1996;44(1):42-4.

12. Rollnick BR, Kaye CI, Nagatoshi K. Oculoauriculovertebral dysplasia and variants: Phenotypic characterstics of 294 patients. AmJ Med Genet. 26(2):361-75

13. Gorlin RJ, Pindborg JJ. Oculoauriculovertebral dysplasia. In: Syndromes of the head and neck. New York: Mc Graw-Hill pg: 546-52.

14. Nakajima H, Goto G, Tanaka N, et al. Goldenhar Syndrome associated with various cardiovascular malformations. Jpn Circ J. 1988;62:617-20.

15. Bayraktar S, Bayraktar ST, Ataoglu E, et al. Goldenhar's syndrome associated with multiple congenital anomalies. J Trop Paediatr. 2005;51(6):377-9.

16. Trivedi HL, Murade S, Harne $\mathrm{S}$, et al. Incomplete presentation of Goldenhar syndrome. Bombay Hosp. 2005;J 49:519-21.

17. Ritchey ML, Narbeekj Huang, Huang C, et al. Urologic manifestations of Goldenhar syndrome. Urology. 1994; 43(1):88-91.
18. Khadilkar VV, Khadilkar AV. Goldenhar syndrome with congenital athyrosis. Indian Pediatrics. 2001;38(12):1419-1421.

19. Amitava das, Biswarup ray, Somnath das, et al. A case of GoldenharGorlin syndrome with unusual association of hypoplastic thumb. Indian J Ophthalmol. 2008;56(2):150-2.

20. Kumar R, Balani B, Patwari AK, et al. Goldenhar syndrome with rare associations. Ind J Pediatr. 2000;67(3):231-33.

21. Saxena R, David MP. Goldenhar Syndrome - A Rare Case Report. J Genet Syndr Gene Ther. 2012;3:113.

22. Sharma JK, Pippal SK, Raghuvanshi SK, et al. Goldenhar-gorlin syndrome: A case report. Indian Journal of Otolaryngology and Head and Neck Surgery. 2006;58(1): 97-101.

23. Barbosa AL, Cavalcanti L, Baptista S, et al. Goldenhar syndrome - case report. Braz Dent J. 2003;14(1): 67-70. 